\title{
The Impact of a Leadership Development Program on Saudi University Students' Perception of Leadership Skills
}

\author{
Amani Hamdan Alghamdi ${ }^{1 *}$, Al-Hattami ${ }^{2}$ \\ ${ }^{1}$ Dr. Amani KHamdan Alghamdi, University of Dammam, Department of Curriculums and Teaching Methods \\ (Dammam), Saudi Arabia. \\ ${ }^{2}$ Dr. Abdulghani Al-Hattami, University of Bahrain, Bahrain Teachers College, Bahrain.
}

\begin{tabular}{l} 
Article Info \\
\hline Article history: \\
Received Feb 12, 2017 \\
Revised Dec 19, 2017 \\
Accepted Feb 12, 2018 \\
\hline
\end{tabular}

\section{Keywords:}

Generic skills, Leadership skills, Perceptions, Students.

\begin{abstract}
This study was conducted to examine whether a leadership training program increases university students' perception of leadership skills. Female students, like their male counterparts, have to play a central role in the economy of the country, regardless of the existing social constraints. Therefore, they need to be equipped with leadership skills in order to ensure that they are capable of making authentic changes in society. The survey included 42 components with seven subscales that were used to measure the following leadership skills: communication, planning, teamwork, decision-making, controlling, motivation and evaluation. The sample consisted of 36 female students who were randomly selected to participate in a two-day leadership training program at the University of Dammam. A questionnaire was distributed at the end of the program. This questionnaire was applied with the objective of estimating the students' perception of the importance of leadership-related skills. The results demonstrate that this program significantly develops participants' perceptions of leadership skills, as $\mathrm{t}(35)=7.81, \mathrm{p}<0.05$, regardless of their area of academic specialization, their history of participation in organized social activities, any previous leadership roles that they may have held, and any previous leadership training that they may have received. The authors recommend that this study be replicated on a larger sample.
\end{abstract}

Copyright $(0) 2018$ Institute of Advanced Engineering and Science. All rights reserved.

\section{Corresponding Author:}

Amani Hamdan Alghamdi

University of Dammam, Department of Curriculums and Teaching Methods (Dammam),

Saudi Arabia.

Email: akhalghamdi@uod.edu.sa

\section{INTRODUCTION}

It has been frequently recommended that, in order to respond to the challenges of the twenty-first century, students be equipped with a foundation of general skills [1]. Leadership skills are among the general skills that are typically characterized as a necessity for all university students and recent graduates. Therefore, much attention is being directed towards the development of leadership skills in contemporary highereducation institutions [2]. As has been explained by a large number of scholars, the primary role of highereducation institutions is to produce highly qualified graduates who are capable of making real changes in workplaces and of contributing to the development of the economy and of society as a whole [3-9]. Leadership is practised in a wide variety of contexts, including at home, at school, at work and in the community [10], [4], [6], [7], [11]. Higher-education institutions should pay more attention to these skills and should have a strategy in place to develop their students' potential.

The reality of the twenty-first century thus far has demonstrated that there exists a wide gap between the needs of the market on the one hand and the actual abilities of university graduates on the other hand. The Program for International Students Assessment (PISA) has indicated that the goal of contemporary education systems should be to help students to acquire soft skills like problem solving, creative thinking, team working, 
and the ability to lead oneself and others effectively rather than to focus exclusively on core subject matter . The Ninth National Plan of the Kingdom of Saudi Arabia acknowledges the fact that graduates from highereducation institutions usually lack many soft skills in general and leadership skills in particular. Leadership skills include the ability to plan, the ability to solve problems and make decisions, and the ability to communicate effectively and manage conflicts [5-7]. Saudi Arabia's National Framework of Graduate Competencies specifically reports that students who are graduating from higher-education institutions should be equipped with general soft skills (such as creative-thinking skills, problem-solving skills and communication skills) in addition to the core subject knowledge.

Although many observers argue that Islam strictly defines the respective roles and responsibilities of each gender [12], many of these gender roles and responsibilities seem to be constructed more by cultural practices than by the Quran and Hadith. This view is reinforced by the fact that, over the centuries, certain preIslamic customs have reappeared and gained a foothold to the extent of strongly influencing the distinction between the genders [13]. Indeed, cultural customs that deny equality to women have become so entrenched in the Arab Muslim culture that they are often accepted as Islamic rules. Yet, many of the customs or rules that are adhered to today cannot be found in the foundational Islamic texts. These cultural traditions and practices were imposed, justified and carried on in Saudi society - and continue to prevail to this day - as a result of male hegemony. Some of these cultural traditions and practices have been sustained through the strategy of ensuring that women illiterate. Women have differing perceptions of the best approaches to negotiating these challenges. One of these approaches is to become a leader.

There are different definitions and understandings of leadership. McNichol [14] states that leaders possess certain distinctive qualities that they bring to bear in leadership situations. Others define leadership as the ability to lead and that leaders have a natural disposition to do this [9,15]. Northouse [15] describes leadership as a process of influence whereby a leader inspires and directs a group of people to achieve a common goal. He further explains that leadership skills can be grouped into three broad categories, namely administrative, interpersonal and conceptual. Administrative skills are comprised of those competencies that enable leaders to run an organization. These competencies include planning, the organization of work activities, the management of resources, and technical skills. Interpersonal skills include oral and written communication skills, the ability to apply emotional intelligence, and the ability to manage and resolve conflicts. Conceptual skills include problem solving and strategic planning.

These leadership skills are essential for students to acquire - not just to ensure their academic success but also to be able to make a positive impact on society. This study is exclusively focused on the seven skills that the academic literature indicates are most important for effective leadership. These skills are communication, planning, teamwork, decision-making, control, motivation and evaluation. Each of these skills is expanded upon below.

\subsection{Communication}

Communication has been identified as the most critical leadership skill. It involves the ability to listen, speak, read body language, ask questions and provide feedback [16]. Any leader needs to be able to articulate goals, and this paves the way for building and sustaining healthy working relationships at every level in an organization. Leaders need to learn to be proficient in communication in order to be able to provide and receive key information. Lack of communication is one of the most serious problems faced by many organizations and it is the source of a vast number of complaints by employees.

Effective communication should take into account the need to maintain confidentiality as appropriate. A leader needs to consistently assess the quality of his or her communication with employees as well as the level of his or her communication skills. Factors that can undermine communication between levels of management and hence can undermine overall organizational performance include some leaders' tendency to talk down or condescend to their employees, excessive use of authority, and the imposition of unanimity on the corporate culture. It is important to avoid placing a focus on winning arguments or on reacting defensively to criticism as this will cause employees to fear openness and thus will hinder the organization's growth.

\subsection{Planning}

Planning is an important aspect of all human activity. As such, it is a key element of the success of any individual or organization. Successful leaders develop and follow detailed plans in order to increase the likelihood that their organization will achieve its specified objectives. As part of their planning process, leaders ought to find answers to the following questions:

1. What do we want to accomplish?

2. Do we engage in brainstorming activities?

3. Before we reach a decision, do we evaluate each option?

4. Do we write down the plan before beginning to execute it? 
5. Do we evaluate the plan after the execution is complete?

6. Do we consider all of the alternatives and do we reflect on the various scenarios that could ensue following the occurrence of unanticipated events?

Leaders should focus their attention and should remain committed to their plans. Planning includes making informed assumptions about the future and engaging in actions in order to positively influence that future. Planning is a necessary skill for successful leadership. From a leadership perspective, a key issue is the extent to which a leader should formulate the plan as an individual undertaking and the extent to which he or she should share the planning function with the members of his or her team. Empirical research and organizational experience confirm that planning is almost invariably more effective if the leader shares the planning function with the members of his or her team.

\subsection{Teamwork}

Teamwork entails working cooperatively as part of a group, and this includes managing team conflicts. One person cannot do it all. The role of the leader is to build and nurture his or her team. An effective leader should play a double role by also incorporating some of the elements of a follower. This means that he or she should listen to and follow sound advice, both from members of the team and from external parties. Moreover, he or she should fulfill the objectives and should implement the instructions that are provided to him or her by higher levels of management. When each team member plays a positive role and makes a tangible contribution, the results are likely to be more than satisfactory. Regardless of his or her position, each team member has to work in harmony with his or her fellow team members and with the organizational hierarchy. The leader ensures that no individual on the team has any doubts about his or her ability and about the group's ability to achieve the various goals. Leaders should instill the belief that the goals can be achieved beyond any reasonable doubt.

\subsection{Decision-making}

A leader must be able to collect and analyze information, to understand events and phenomena as they occur, to make decisions with confidence, and to take action based on those decisions. Making decisions too quickly or too slowly will tend to interfere with leadership effectiveness. Decisions affect the quality and the direction of any organization. Therefore, decisions should only be taken after careful consideration of the evidence and of all relevant factors and scenarios. A leader is the person who "... is able to communicate, to make sound decisions, and to get things done with and through people" [17].

\subsection{Control}

Controlling is the process of ensuring that all of the team's energy is directed towards achieving the collective goals. On the occasions when there is a decline in this level of energy, the leader's role is to restore it to its former intensity. There is a natural instinct for leaders to rely as much as possible on their team members' self-control or self-discipline. A better-managed and more cohesive team with competent and highly motivated individual members will provide more scope for managers to engage in this kind of reliance.

\subsection{Motivation}

There exists a variety of ways to motivate people, including through such inducements as rewards and/or punishments. Team members will individually and collectively perform to a higher standard if they are motivated. An effective leader must understand the underlying needs of all human beings, as these form the foundation for the idiosyncratic needs of each individual team member. In this regard, Abraham Maslow's [18, 19] concept of a hierarchy of needs continues to offer valuable insight. He suggested that individual needs are arranged in a hierarchy of priority, with the more foundational needs related to physical survival being positioned at the bottom and with the non-vital but nonetheless important needs related to social interaction and personal development (or "self-actualization") being positioned near or at the top. The best leaders are able to tap into and leverage this hierarchy of needs to motivate their team members to achieve goals that extend far beyond their original expectations and even their original aspirations [20].

\subsection{Evaluation}

The ability to evaluate is a crucial skill that every leader should possess as this skill plays an indispensable role in maintaining and improving organizational performance. Typically, an organization sets a variety of goals and then works towards achieving them. This process will not result in the intended level of development unless there is in place a performance-evaluation process and hence a basis for providing feedback to the members of the team. Performance has to be judged against the standard of the organization's objectives. Team members need to know and understand their position in relation to the desired end results. Team 
performance should be evaluated on a constant basis because no team is perfect. Many are good, a few are very good, and even fewer are excellent.

Many observers believe that leadership is a skill set that can be developed and nurtured in order to ensure the effective accomplishment of tasks and objectives. Leadership is comprised of skills or competencies that can be learned and developed $[21,9,15]$. No person is a natural-born leader; everyone can develop leadership skills and everyone can benefit from their use. Leadership is more of an ability than a skill if one improve their communication skills their ability to lead will improve. This study was conducted with the goal of evaluating this distinction. The primary aim was to examine whether and to what extent a two-day leadership program can improve students' perceptions about leadership as a skill. Students' perceptions are considered to be a good source for collecting important information [22]. The following research questions were investigated in this study:

1. How efficient is the training program in terms of developing university students' appreciation of leadership skills?

2. Does students' appreciation of leadership skills differ according to their general area of specialization that is, arts (social sciences and/or humanities) versus sciences (natural sciences)?

3. Does students' appreciation for leadership skills differ according to their participation in organized social activities (participants versus non-participants)?

4. Does students' appreciation of leadership skills differ according to their participation in leadership development activities (participants versus non-participants)?

5. Does students' appreciation of leadership skills differ according to their training in leadership (previous leadership training versus no previous leadership training)?

\section{RESEARCH METHOD \\ 2.1 Subjects}

The sample consisted of 36 undergraduate students. Students were chosen at random after approximately 246 students registered to participate in a two-day leadership-skills workshop that covered communication, planning, teamwork, decision-making, control, motivation and evaluation. Only 36 students were selected because this total is the specified capacity of the program. The program is implemented on an annual basis within the University of Dammam with the objective of enhancing students' leadership skills. More specifically, the program is aimed at introducing students to the following: the characteristics of successful and unsuccessful leaders; effective strategies and tactics to develop leadership skills; techniques to build self-confidence; the importance and role of emotional intelligence and various techniques to develop it; the creation of an inspiring vision of the future; leaders' strategies and actions to motivate their followers to achieve their vision; and leaders' approaches to make effective use of their own efforts and those of their team members through the implementation of the skills of prioritization, delegation, persuasion and decisionmaking. The students were asked to respond to a survey before and after their participation in the program. Table 1 shows the participating students' distribution with respect to four important categories: area of academic specialization, participation in organized social activities, the taking of leadership roles in school activities and previous leadership-skills training.

Table 1. Detailed Overview the Study Sample

\begin{tabular}{|c|c|c|c|}
\hline Categories of the Sample & Variable Groups & Number & Percentage \\
\hline \multirow{3}{*}{$\begin{array}{l}\text { Students' area of } \\
\text { specialization }\end{array}$} & Sciences & 20 & $56 \%$ \\
\hline & Arts & 16 & $44 \%$ \\
\hline & Total & 36 & $100 \%$ \\
\hline \multirow{3}{*}{$\begin{array}{l}\text { Participation in } \\
\text { organized social } \\
\text { activities }\end{array}$} & Participants in organized social activities & 17 & $47 \%$ \\
\hline & Non-participants in organized social activities & 19 & $53 \%$ \\
\hline & Total & 36 & $100 \%$ \\
\hline \multirow{3}{*}{$\begin{array}{l}\text { Taking of leadership } \\
\text { roles in school activities }\end{array}$} & Participants in leadership roles & 16 & $44 \%$ \\
\hline & Non-participants in leadership roles & 20 & $56 \%$ \\
\hline & Total & 36 & $100 \%$ \\
\hline \multirow{3}{*}{$\begin{array}{l}\text { Leadership-skills } \\
\text { training }\end{array}$} & Previous leadership training & 15 & $42 \%$ \\
\hline & No previous leadership training & 21 & $58 \%$ \\
\hline & Total & 36 & $100 \%$ \\
\hline
\end{tabular}

\subsection{Instrument}

The questionnaire in its preliminary form was reviewed by three education specialists who are also interested in leadership development. Their objective was to assess the questionnaire in terms of general wording and specifically in terms of the relationship of each word to each targeted skill. In addition, the survey 
was piloted in 2014 on a sample that consisted of 20 University of Dammam students and was found to be reliable with a coefficient index of 0.72 . The questionnaire was applied to them in order to assess their understanding of the importance of leadership and their understanding of the various core leadership skills. The level of consistency was calculated by specifying the correlation coefficient between each of the axes in the questionnaire and the total degree. The result was as follows:

Table 2. Leadership Skill Correlation Coefficient

\begin{tabular}{lc}
\hline \multicolumn{1}{c}{ Leadership Skill } & Correlation Coefficient \\
\hline Communication skills & $0.787^{* *}$ \\
Planning skills & $0.683^{* *}$ \\
Team-performance regulation & $0.861^{* *}$ \\
skills & $0.880^{* *}$ \\
Decision-making skills & $0.895^{* *}$ \\
Controlling skills & $0.725^{* *}$ \\
Motivation skills & $0.784^{* *}$ \\
Evaluation skills & \\
\hline
\end{tabular}

According to the data set out in Table 2, the correlation coefficients ranged from 0.63 to 0.90 . The Cronbach's alpha coefficient was also calculated and was found to be 0.89 , thus confirming the consistency of the questionnaire.

\section{RESULTS AND DISCUSSION}

The results of this study indicate that the program in question significantly developed the participating university students' appreciation of leadership skills. The results support the provision of many workshops to improve leadership skills and thus respond to the conclusion of the Ninth National Plan of Kingdom of Saudi Arabia that graduates from higher-education institutions lack many soft skills in general and leadership skills in particular. Table 1 shows the t-test results for the pre- and post-implementation of the leadership-skills program. The overall findings indicate the significance of the difference between the students' perceptions before and after the delivery of the program, $t(35)=7.81, \mathrm{p}<0.05$. The table also shows the results for each leadership sub-skill, all of which have indicated significant differences.

Table 3. Pre and Post Statistics for the Application of the Leadership Skills Program

\begin{tabular}{|c|c|c|c|c|c|c|}
\hline \multirow{2}{*}{ Leadership Skills } & \multicolumn{2}{|c|}{ Pre-application } & \multicolumn{2}{|c|}{ Post-application } & \multirow{2}{*}{$d f$} & \multirow{2}{*}{$t$-value } \\
\hline & Mean & $\mathrm{SD}$ & Mean & SD & & \\
\hline Planning skills & 23.833 & 5.051 & 28.722 & 1.951 & 35 & $* * 6.873$ \\
\hline Decision-making skills & 24.556 & 4.312 & 28.028 & 3.038 & 35 & $* * 6.11$ \\
\hline Controlling skills & 23.806 & 5.126 & 28.139 & 3.261 & 35 & $* * 5.346$ \\
\hline All Skills & 169.167 & 27.041 & 199.944 & 13.84 & 35 & $* * 7.81$ \\
\hline
\end{tabular}

The details for each of the leadership-skill questions pre and post the delivery of the program can be seen in Appendix (A). The results for the first research question indicate that there were significant differences in the students' perceptions about leadership skills before and after their participation in the leadership-training program. These results are consistent with those of $[21,9,15]$, in particular with the finding that leadership skills or competencies can be learned and developed. The analyses set out hereunder examine whether this significant difference is a function of students' categorization into arts and science majors, participation in organized social activities, participation in leadership activities and previous involvement in leadership training.

All of the results of the t-test statistics show that there were no significant differences in the students' perceptions based on their personal categorizations. In other words, the data indicate that the program significantly develops student participants' perceptions about leadership skills regardless of their area of academic specialization, their participation in organized social activities, their involvement in leadership roles or their previous leadership training (as shown in Tables 5-8). 
Table 4. Pre and Post Statistics for the Application of the Leadership Skills Program According to Area of Academic Specialization (Arts versus Science)

\begin{tabular}{lcccccc}
\hline \multirow{2}{*}{ Leadership Skills } & \multicolumn{2}{c}{ Pre-application } & \multicolumn{2}{c}{ Post-application } & \multirow{2}{*}{$d f$} & \multirow{2}{*}{$t$-value } \\
\cline { 2 - 5 } & Mean & SD & Mean & SD & & \\
\hline Communication skills & 28.45 & 2.282 & 28.625 & 1.544 & 34 & -0.262 \\
Planning skills & 28.45 & 2.395 & 29.063 & 1.181 & 34 & -0.934 \\
Team-performance regulation & 28.8 & 1.963 & 28.688 & 1.778 & 34 & 0.178 \\
skills & 28.15 & 2.961 & 27.875 & 3.222 & 34 & 0.266 \\
Decision-making skills & 28.3 & 3.011 & 27.938 & 3.642 & 34 & 0.327 \\
Controlling skills & 28.3 & 1.455 & 28.75 & 2.017 & 34 & 0.95 \\
Motivation skills & 29.1 & 2.49 & 28.25 & 3.975 & 34 & 0.784 \\
Evaluation skills & 200.55 & 14.763 & 199.188 & 13.029 & 34 & 0.29 \\
All Skills & & & & & &
\end{tabular}

Table 5. Pre and Post Statistics for the Application of Leadership Skills Program According to Participation in Organized Social Activities

\begin{tabular}{|c|c|c|c|c|c|c|}
\hline \multirow[t]{2}{*}{ Leadership Skills } & \multicolumn{2}{|c|}{$\begin{array}{l}\text { Participants in in Organized } \\
\text { Social Activities }(\mathrm{n}=17)\end{array}$} & \multicolumn{2}{|c|}{$\begin{array}{c}\text { Non-participants inin Organized } \\
\text { Social Activities }(n=19)\end{array}$} & \multirow[t]{2}{*}{$d f$} & \multirow[t]{2}{*}{$t$-value } \\
\hline & Mean & $\mathrm{SD}$ & Mean & SD & & \\
\hline Communication skills & 29 & 1.414 & 28.105 & 2.407 & 34 & 1.382 \\
\hline Planning skills & 28.824 & 1.629 & 28.632 & 2.241 & 34 & 0.291 \\
\hline $\begin{array}{l}\text { Team-performance regulation } \\
\text { skills }\end{array}$ & 29.059 & 1.088 & 28.474 & 2.342 & 34 & 0.942 \\
\hline Decision-making skills & 27.353 & 3.481 & 28.632 & 2.521 & 34 & -1.272 \\
\hline Controlling skills & 28.471 & 2.427 & 27.842 & 3.905 & 34 & 0.572 \\
\hline Motivation skills & 29.177 & 1.551 & 28.947 & 1.9 & 34 & 0.393 \\
\hline Evaluation skills & 28.294 & 3.885 & 29.105 & 2.514 & 34 & -0.752 \\
\hline All Skills & 200.177 & 12.249 & 199.737 & 15.459 & 34 & 0.094 \\
\hline
\end{tabular}

Table 6. Pre and Post Statistics for the Application of the Leadership Skills Program According to Previous Participation in Leadership Activities

\begin{tabular}{lcccccc}
\hline \multirow{2}{*}{ Leadership Skills } & \multicolumn{2}{c}{ Pre-application } & \multicolumn{2}{c}{ Post-application } & \multirow{2}{*}{ t } & \multirow{2}{*}{$t$-value } \\
\cline { 2 - 5 } & Mean & SD & Mean & SD & & \\
\hline Communication skills & 28.875 & 1.628 & 28.25 & 2.197 & 34 & 0.948 \\
Planning skills & 28.813 & 1.87 & 28.65 & 2.059 & 34 & 0.245 \\
Team-performance regulation skills & 28.688 & 1.852 & 28.8 & 1.908 & 34 & -0.178 \\
Decision-making skills & 28.688 & 1.957 & 27.5 & 3.649 & 34 & 1.172 \\
Controlling skills & 28.25 & 3.697 & 28.05 & 2.964 & 34 & 0.18 \\
Motivation skills & 29.188 & 1.797 & 28.95 & 1.701 & 34 & 0.406 \\
Evaluation skills & 29.438 & 0.727 & 28.15 & 4.221 & 34 & 1.202 \\
All Skills & 201.938 & 10.573 & 198.35 & 16.08 & 34 & 0.768 \\
\hline
\end{tabular}

Table 7. Pre and Post Statistics for the Application of the Leadership Skills Program According to Previous Leadership Training (Previous Leadership Training versus No Previous Leadership Training)

\begin{tabular}{|c|c|c|c|c|c|c|}
\hline \multirow[t]{2}{*}{ Leadership Skills } & \multicolumn{2}{|c|}{$\begin{array}{l}\text { Previous Leadership } \\
\text { Skills Training }(\mathrm{n}=15)\end{array}$} & \multicolumn{2}{|c|}{$\begin{array}{l}\text { No Previous Leadership } \\
\text { Skills Training }(n=21)\end{array}$} & \multirow[t]{2}{*}{$d f$} & \multirow[t]{2}{*}{$t$-value } \\
\hline & Mean & SD & Mean & $\mathrm{SD}$ & & \\
\hline Communication skills & 28.333 & 1.676 & 28.667 & 2.176 & 34 & -0.497 \\
\hline Planning skills & 28.6 & 1.595 & 28.81 & 2.205 & 34 & -0.314 \\
\hline Team-performance regulation skills & 28.8 & 1.897 & 28.714 & 1.875 & 34 & 0.135 \\
\hline Decision-making skills & 27.733 & 2.815 & 28.238 & 3.239 & 34 & -0.486 \\
\hline Controlling skills & 27.533 & 3.889 & 28.571 & 2.749 & 34 & -0.94 \\
\hline Motivation skills & 28.933 & 1.981 & 29.143 & 1.558 & 34 & -0.355 \\
\hline Evaluation skills & 29.4 & 0.986 & 28.238 & 4.098 & 34 & 1.072 \\
\hline All Skills & 199.333 & 11.721 & 200.381 & 15.445 & 34 & -0.221 \\
\hline
\end{tabular}

\section{CONCLUSION}

Leadership skills are indispensable to the development of Saudi Arabia. Without a full complement of leadership skills, young university graduates are unable to navigate the complex and sometimes treacherous waters of the age in which we live. It is effectively impossible to become a successful person if one lacks leadership skills. The government of the Kingdom of Saudi Arabia has acknowledged that leadership is one of the five domains of learning and is taking concrete steps to incorporate leadership training into the postsecondary education system. The National Commission for Academic Accreditation and Assessment requires 
that all faculty members teach these skills to their students. Saudi Arabia's universities have responded to this call by assisting professors and instructors with the implementation of strategies and techniques for teaching leadership. These institutions also offer an annual leadership-training workshop to selected students in order to reinforce the importance of acquiring and using leadership skills.

The results of this study confirm the fact that the above-described leadership-development program changes students' perceptions about leadership and leadership skills. The importance of leadership skills is acknowledged when they are implemented by the participating students, regardless of their field of academic specialization and regardless of their previous leadership experience. The teaching of soft skills including leadership skills is no longer a matter of choice. It is a compulsory undertaking that runs through all areas of instruction. Professors and instructors should pay close attention to these skills and should try to integrate them into all of their academic programs in order to enable graduates to effectively respond to twenty-first century challenges, both in the workplace and in the global community.

\section{REFERENCES}

1 Bennis, W. Managing the dream: Leadership in the 21st century. Training: The Magazine of Human Resource Development, 27(5), 44-46, 1990.

2 Fullan, M. G. The new meaning of educational change. New York, NY: Teachers College Press.

3 Casner-Lotto, J., Barrington, L., Wright, M. (2006). Are they really ready to work? Employers' perspectives on the basic knowledge and applied skills of new entrants to the 21st century U.S. workforce. New York, NY: Conference Board, 1991.

4 Banerji, S. Employers say college graduates lack essential skills to succeed in today's global economy. Diverse Issues in Higher Education, 23(26), 18-18, 2007.

5 Johnson, P. The 21st century skills movements. Educational Leadership, 67(1), 1-11, 2009.

6 Trilling, B., Fadel, C. 21 st century skills: Learning for life in our times. San Francisco, CA: Jossey-Bass; Chichester, UK: John Wiley, 2009.

7 Bellanca, J. A., Brandt, R. S. 21st century skills: Rethinking how students learn. Bloomington, IN: Solution Tree Press, 2010.

8 Dixon J., Belnap, C., Albrecht, C., Lee, K. The importance of soft skills. Corporate Finance Review, 14(6), 35-38, 2010.

9 Yoon, H. J., Song, J. H., Donahue, W. E., Woodley, K. K. Leadership competency inventory: A systematic process of developing and validating a leadership competency scale. Journal of Leadership Studies, 4(3), 39-51, 2010.

10 Beer, M., Eisenstat, R. A., Spector, B. Why change programs don't produce change. Harvard Business Review, 68(6), 158-166, 1990.

11 AlMunajjed, M. Where the real worth is .Retrieved Jan 22, 2014, from http://www.arabianbusiness.com/where-realwealth-is-457262.html, 2012.

12 Vidyasagar, G., Rea, D. M. Saudi women doctors: Gender and careers within Wahhabic Islam and a 'Westernized' work culture. Women's Studies International Forum, 27(3), 261-280, 2004.

13 Jawad, H. The rights of women in Islam: An authentic approach. London, UK: Macmillan Press, 1998.

14 McNichol, E. Measure your leadership skills. Nursing Standard, 15(22), 77-77, 2001.

15 Northouse, P. G. Introduction to leadership: Concepts and practice. Thousand Oaks, CA.: Sage Publications, 2012.

16 Barrett, D. J. Leadership communication. New York, NY: McGraw-Hill, 2006.

17 Bowman, G. W., Jones, L. W., Peterson, R. A., Gronouski, J. A., Mahoney, R. M. What helps or harms promotability? Harvard Business Review, 42(1), 6-18, 1964.

18 Maslow, A. H. A theory of human motivation. Psychological Review, 50(4), 370-396, 1943.

19 Maslow, A. H. Motivation and personality. New York, NY: Harper, 1954.

20 Bass, B. M., Stogdill, R. M. Bass \& Stogdill's handbook of leadership: Theory, research, and managerial applications (3rd ed.). New York, NY: Free Press, 1990.

21 De Pree, M. Leadership is an art. New York, NY: Doubleday, 1989.

22 Bellon, T., Beaudry, J. Teachers' perceptions of their leadership roles in site-based decision making. Paper presented at the Annual Meeting of the American Educational Research Association, San Francisco, CA, 1992. 


\section{Appendix (A)}

Table 8. Pre and Post Statistics for the Application of the Leadership Skills Program Compared to the the Axis of Communication Skills

\begin{tabular}{|c|c|c|c|c|c|}
\hline \multirow{2}{*}{ No. } & \multirow{2}{*}{ Leadership Skill } & \multicolumn{2}{|c|}{ Pre-training } & \multicolumn{2}{|c|}{ Post-training } \\
\hline & & Mean & Percentage & Mean & Percentage \\
\hline 1 & $\begin{array}{l}\text { Understands fellow team members' } \\
\text { thoughts and feelings }\end{array}$ & 3.92 & $78 \%$ & 4.86 & $97 \%$ \\
\hline 2 & Has effective communication skills & 4.28 & $86 \%$ & 4.75 & $95 \%$ \\
\hline 3 & Manages meetings effectively & 4.11 & $82 \%$ & 4.75 & $95 \%$ \\
\hline 4 & $\begin{array}{l}\text { Uses various communication means in a } \\
\text { creative way }\end{array}$ & 4.03 & $81 \%$ & 4.72 & $94 \%$ \\
\hline 5 & $\begin{array}{l}\text { Exhibits the attitude that he or she } \\
\text { demands from team members }\end{array}$ & 4.28 & $86 \%$ & 4.64 & $93 \%$ \\
\hline 6 & $\begin{array}{l}\text { Motivates team members towards } \\
\text { accomplishing tasks }\end{array}$ & 4.33 & $87 \%$ & 4.81 & $96 \%$ \\
\hline & Total Mean & 4.16 & $83 \%$ & 4.75 & $95 \%$ \\
\hline
\end{tabular}

Table 9. Pre and Post Statistics for the Application of the Leadership Skills Program Concerning the Axis of Developing Planning Skills

\begin{tabular}{clcccc}
\hline \multirow{2}{*}{ No. } & Leadership Skill & \multicolumn{2}{c}{ Pre-training } & \multicolumn{2}{c}{ Post-training } \\
\cline { 2 - 5 } & Mean & Percentage & Mean & Percentage \\
\hline 1 & $\begin{array}{l}\text { Frames work goals in a clear manner } \\
\text { Specifies accurately the necessary means }\end{array}$ & 4.11 & $82 \%$ & 4.81 & $96 \%$ \\
& $\begin{array}{l}\text { and tools to accomplish the specified work } \\
3\end{array}$ & 4.08 & $82 \%$ & 4.86 & $97 \%$ \\
& $\begin{array}{l}\text { Adjusts the action plan in a flexible manner } \\
\text { according to the nature of the required work }\end{array}$ & 4.06 & $81 \%$ & 4.78 & $96 \%$ \\
& $\begin{array}{l}\text { Displays the ability to formulate alternative } \\
\text { plans in the event of an emergency }\end{array}$ & 3.67 & $73 \%$ & 4.58 & $92 \%$ \\
6 & $\begin{array}{l}\text { Divides the work into subsidiary missions } \\
\text { Situates the time plan adequately to }\end{array}$ & 4.11 & $82 \%$ & 4.83 & $97 \%$ \\
& $\begin{array}{l}\text { accomplish team missions } \\
\text { Total Mean }\end{array}$ & 3.81 & $76 \%$ & 4.86 & $97 \%$ \\
\end{tabular}

Table 10. Pre and Post Statistics for the Application of the Leadership Skills Program Concerning the Axis of Monitoring Team Members' Performance

\begin{tabular}{|c|c|c|c|c|c|}
\hline \multirow{2}{*}{ No. } & \multirow{2}{*}{ Leadership Skill } & \multicolumn{2}{|c|}{ Pre-training } & \multicolumn{2}{|c|}{ Post-training } \\
\hline & & Mean & Percentage & Mean & Percentage \\
\hline 1 & $\begin{array}{l}\text { Determines the rights and responsibilities of each member of } \\
\text { the team }\end{array}$ & 3.08 & $62 \%$ & 4.75 & $95 \%$ \\
\hline 2 & $\begin{array}{l}\text { Directs each team member to work that is compatible with his } \\
\text { or her abilities }\end{array}$ & 4.11 & $82 \%$ & 4.81 & $96 \%$ \\
\hline 3 & $\begin{array}{l}\text { Frames clear standards of performance for the team members } \\
\text { and for the team in general }\end{array}$ & 4.06 & $81 \%$ & 4.78 & $96 \%$ \\
\hline 4 & Monitors any improper behaviour of team members & 3.81 & $76 \%$ & 4.67 & $93 \%$ \\
\hline 5 & $\begin{array}{l}\text { Adjusts the course of action in order to take into account any } \\
\text { clear disruption to the team's activities }\end{array}$ & 4.22 & $84 \%$ & 4.83 & $97 \%$ \\
\hline 6 & $\begin{array}{l}\text { Reinforces the team's behaviour according their } \\
\text { accomplishment }\end{array}$ & 4.33 & $87 \%$ & 4.92 & $98 \%$ \\
\hline & Total Mean & 3.93 & $79 \%$ & 4.79 & $96 \%$ \\
\hline
\end{tabular}

Table 11. Pre and Post Statistics for the Application of the Leadership Skills Program Concerning the Axis of Monitoring Team Members' Performance

\begin{tabular}{|c|c|c|c|c|c|}
\hline \multirow{2}{*}{ No. } & \multirow{2}{*}{ Leadership Skill } & \multicolumn{2}{|c|}{ Pre-training } & \multicolumn{2}{|c|}{ Post-training } \\
\hline & & Mean & Percentage & Mean & Percentage \\
\hline 1 & $\begin{array}{l}\text { Frames decisions in a clear and specific } \\
\text { manner }\end{array}$ & 3.97 & $79 \%$ & 4.75 & $95 \%$ \\
\hline 2 & Chooses the right time to make a decision & 4 & $80 \%$ & 4.67 & $93 \%$ \\
\hline 3 & $\begin{array}{l}\text { Has strong arguments and proofs that } \\
\text { justify his or her decision-making }\end{array}$ & 3.94 & $79 \%$ & 4.69 & $94 \%$ \\
\hline 4 & $\begin{array}{l}\text { Able to foresee possible difficulties and } \\
\text { risks during decision implementation }\end{array}$ & 4.03 & $81 \%$ & 4.61 & $92 \%$ \\
\hline 5 & $\begin{array}{l}\text { Takes responsibility for the decisions that } \\
\text { he or she makes }\end{array}$ & 4.22 & $84 \%$ & 4.53 & $91 \%$ \\
\hline 6 & $\begin{array}{l}\text { Ensures the team members' commitment in } \\
\text { implementing decisions }\end{array}$ & 4.39 & $88 \%$ & 4.78 & $96 \%$ \\
\hline & Total Mean & 4.09 & $82 \%$ & 4.67 & $93 \%$ \\
\hline
\end{tabular}


Table 12. Pre and Post Statistics for the Application of the Leadership Skills Program Concerning Correcting Skills Axis

\begin{tabular}{|c|c|c|c|c|c|}
\hline \multirow{2}{*}{ No. } & \multirow{2}{*}{ Leadership Skill } & \multicolumn{2}{|c|}{ Pre-training } & \multicolumn{2}{|c|}{ Post-training } \\
\hline & & Mean & Percentage & Mean & Percentage \\
\hline 1 & $\begin{array}{l}\text { Sets clear evaluation standards for the } \\
\text { subsidiary missions in an accurate way }\end{array}$ & 4 & $80 \%$ & 4.64 & $93 \%$ \\
\hline 2 & $\begin{array}{l}\text { Balances the performance standards of } \\
\text { members and groups within the team }\end{array}$ & 3.86 & $77 \%$ & 4.75 & $95 \%$ \\
\hline 3 & $\begin{array}{l}\text { Includes development plans for team } \\
\text { performance according to the evaluation } \\
\text { of results }\end{array}$ & 3.94 & $79 \%$ & 4.72 & $94 \%$ \\
\hline 4 & Analyzes the team's abilities accurately & 4 & $80 \%$ & 4.67 & $93 \%$ \\
\hline 5 & $\begin{array}{l}\text { Balances quantitative and qualitative } \\
\text { standards to ensure the accomplishment of } \\
\text { the team's goals }\end{array}$ & 3.92 & $78 \%$ & 4.61 & $92 \%$ \\
\hline 6 & $\begin{array}{l}\text { Establishes links between the team } \\
\text { members' performance evaluation and } \\
\text { their special abilities }\end{array}$ & 4.08 & $82 \%$ & 4.75 & $95 \%$ \\
\hline & Total Mean & 3.97 & $79 \%$ & 4.69 & $94 \%$ \\
\hline
\end{tabular}

Table 13. Pre and Post Statistics for the Application of the Leadership Skills Program Concerning Directive Skills

\begin{tabular}{|c|c|c|c|c|c|}
\hline \multirow{2}{*}{ No. } & \multirow{2}{*}{ Leadership Skill } & \multicolumn{2}{|c|}{ Pre-training } & \multicolumn{2}{|c|}{ Post-training } \\
\hline & & Mean & Percentage & Mean & Percentage \\
\hline 1 & Has the ability to point out the & & & & \\
\hline & $\begin{array}{l}\text { psychological and spiritual sides of the } \\
\text { team }\end{array}$ & 3.78 & $76 \%$ & 4.81 & $96 \%$ \\
\hline 2 & $\begin{array}{l}\text { Cares about problems that could affect } \\
\text { team members negatively }\end{array}$ & 4.06 & $81 \%$ & 4.89 & $98 \%$ \\
\hline 3 & $\begin{array}{l}\text { Is keen to maintain constant awareness } \\
\text { of the team in order to avoid } \\
\text { performance deficiencies }\end{array}$ & 4.19 & $84 \%$ & 4.89 & $98 \%$ \\
\hline 4 & $\begin{array}{l}\text { Allocates time to direct unsupervised } \\
\text { team members }\end{array}$ & 3.86 & $77 \%$ & 4.86 & $9 \%$ \\
\hline 5 & $\begin{array}{l}\text { Directs team members with special } \\
\text { abilities towards tasks that build on } \\
\text { their areas of strength }\end{array}$ & 4.11 & $82 \%$ & 4.81 & $96 \%$ \\
\hline 6 & $\begin{array}{l}\text { Holds general directive sessions for the } \\
\text { team members according to the } \\
\text { required tasks }\end{array}$ & 3.94 & $79 \%$ & 4.81 & $96 \%$ \\
\hline & Total Mean & 3.99 & $80 \%$ & 4.84 & $97 \%$ \\
\hline
\end{tabular}

Table 14. Pre and Post Statistics for the Application of the Leadership Skills Program Concerning Investing in the Abilities and Resources Axis

\begin{tabular}{|c|c|c|c|c|c|}
\hline \multirow{2}{*}{ No. } & \multirow{2}{*}{ Leadership Skill } & \multicolumn{2}{|c|}{ Pre-training } & \multicolumn{2}{|c|}{ Post-training } \\
\hline & & Mean & Percentage & Mean & Percentage \\
\hline 1 & $\begin{array}{l}\text { Invests in the resources and abilities of team } \\
\text { members to determine the best possible } \\
\text { achievement }\end{array}$ & 4 & $80 \%$ & 4.75 & $95 \%$ \\
\hline 2 & $\begin{array}{l}\text { Directs team members to work that is } \\
\text { compatible with their abilities and preferences }\end{array}$ & 4.25 & $85 \%$ & 4.83 & $97 \%$ \\
\hline 3 & $\begin{array}{l}\text { Specifies the strategies that need less time and } \\
\text { effort to implement the required tasks }\end{array}$ & 4.08 & $82 \%$ & 4.72 & $94 \%$ \\
\hline 4 & $\begin{array}{l}\text { Is keen to invest the budget in a way that } \\
\text { serves the achievement of team goals }\end{array}$ & 4.19 & $84 \%$ & 4.75 & $95 \%$ \\
\hline 5 & $\begin{array}{l}\text { Has the ability to maintain the interest of team } \\
\text { members during the execution of their required } \\
\text { tasks }\end{array}$ & 4.06 & $81 \%$ & 4.72 & $94 \%$ \\
\hline 6 & $\begin{array}{l}\text { Benefits from previous experiences in } \\
\text { supporting the team in future tasks }\end{array}$ & 3.89 & $78 \%$ & 4.94 & $99 \%$ \\
\hline & Total Mean & 4.08 & $82 \%$ & 4.79 & $96 \%$ \\
\hline
\end{tabular}

